\title{
Temporal variation in the structure of reef slope fish communities (central Great Barrier Reef): short-term effects of Acanthaster planci infestation*
}

\author{
David McB. Williams \\ Australian Institute of Marine Science, PMB No. 3, Townsville MC, Townsville, Queensland 4810, Australia
}

\begin{abstract}
Temporal and spatial variation in the abundance of acanthurids, caesionids, chaetodontids, labrids, pomacentrids, scarids and siganids was examined on reefs of the central Great Barrier Reef over 4 yr. The reef slopes of 3 outer shelf reefs, 4 mid-shelf reefs and 2 nearshore reefs were first surveyed by visual censuses in 1980. In early 1983 large numbers of the coral-feeding starfish Acanthaster planci appeared at the base of the slopes of 3 of the mid-shelf reefs. By early 1984 live coral cover on the shallow slopes of these 3 reefs had been reduced by 55 to $90 \%$. The fish communities on each of the reefs were re-surveyed in 1983 and 1984. In 1980, differences in composition of fish communities at similar cross-shelf locations (measured by percentage of species examined that differed significantly in abundance between reefs) ranged from 2 to $29 \%$ (mean $=15 \%$ ). Differences between reefs at different locations ranged from 46 to $82 \%$ (mean $=69 \%$ ). Temporal changes in the composition of communities within reefs between 1980 and 1983 ranged from 0 to $5 \%$ (mean $=3 \%$ ) on those reefs unaffected by $A$. planci and from 7 to $15 \%$ (mean $=10 \%$ ) on the affected reefs. Changes in the abundances of scleractinian-feeding chaetodontids, but not of other species, could be readily attributed to changes in the reefs caused by $A$. planci.
\end{abstract}

\section{INTRODUCTION}

The structure of communities of fishes on reef slopes varies greatly among reefs of the central Great Barrier Reef (hereafter GBR). Significant differences occur in the abundances of some species among adjacent reefs and far greater differences occur in community structure (absolute and relative abundances of species, trophic structure, diversity) among reefs at different locations across the continental shelf (nearshore, midshelf, outer shelf) (Williams 1982, Wiliams \& Hatcher 1983). These among-reef comparisons of communities of fishes of the reef slopes have recently been extended to studies of assemblages of herbivores among different zones within and among reefs of the central GBR (Russ $1984 \mathrm{a}, \mathrm{b}$ ) and to among-reef comparisons of reef slope communities at 8 different latitudes from the far

\footnotetext{
- Contribution No. 305 from the Australian Institute of
} Marine Science

(c) Inter-Research/Printed in F. R. Germany northern GBR $\left(11^{\circ} \mathrm{S}\right)$ to the Capricorn-Bunker group $\left(23^{\circ} 30^{\prime} \mathrm{S}\right)$ in the south (Williams 1983).

Interpretation of the significance of this spatial variation requires some knowledge of temporal variation in the patterns. Significant temporal variation in the structure of assemblages at the local scale (e.g. Talbot et al, 1978, Sale \& Douglas 1984, Williams 1980) and major perturbations of the system such as those caused by infestations of the crown-of-thorns starfish Acanthaster planci (e.g. Endean 1973) suggest that constancy of spatial patterns cannot be assumed.

Initial studies of the central GBR reef slope communities were made in 1980 (Williams 1982). In early 1983 large numbers of the coral-feeding Acanthaster planci appeared on 3 of the mid-shelf reefs studied. By early 1984, live coral cover on the shallow slopes of Rib, John Brewer and Lodestone reefs had been reduced (from 72,66 and $66 \%$ respectively) by approximately 55, 70 and $90 \%$ respectively. While such a perturbation of the benthic community might be expected to have a significant influence on the associ- 
ated fish communities this is the first opportunity to test the hypothesis in the form of a natural experiment. Previous studies of the effects of $A$. planci on fish communities are restricted to anecdotal observations (e.g. Chesher 1969, Cheney 1972, Endean \& Stablum 1973) and comparisons of fish assemblages on living and dead colonies of Acropora (Sano et al. 1984).

My aim was first to determine the extent of temporal variation in the abundances of individual species within a reef, relative to spatial differences between adjacent reefs and among shelf locations, and second to determine the short-term effects of Acanthaster planci infestations on the fish communities of the reef slopes.

\section{METHODS}

The locations of the study reefs are illustrated in Fig. 1. Details of the locations of study sites within reefs and their associated coral communities are given in Williams (1982). The fish communities were surveyed using the species list and visual census technique described in Williams (1982). The species list contains a total of 146 species including: all species of chaetodontid in the area, the majority of the common pomacentrids (47 spp.) and acanthurids (19 spp.), virtually all scarids (21 spp.), selected labrids (13 spp.), caesionids ( 3 spp.) and siganids ( $5 \mathrm{spp}$.).

A census dive involved a 45 min swim (using SCUBA) along the reef slope, swimming in a zig-zag pattern up and down the reef face from the surface to a depth of $13 \mathrm{~m}$ and recording the presence of species and their abundance (on a $\log _{5}$ abundance scale) along oblique transects stretching approximately $5 \mathrm{~m}$ either side of the diver. All data were recorded on prepared census forms of water-proof paper and all censuses were made by 1 observer (the author) to ensure consistency. Five censuses of non-overlapping area of reef slope were made on each reef (except on Davies where only 4 censuses were made). Each 45 min swim covered approximately $150 \mathrm{~m}$ of reef front.

To determine temporal variation, the 1980 surveys were repeated on 1 outer shelf reef (Myrmidon), 3 midshelf (Rib, John Brewer and Lodestone) and 1 nearshore reef (Pandora) in October-November 1983. Effects of Acanthaster planci on fishes were further examined by surveys in June 1984 of the 3 mid-shelf reefs plus a control reef on the mid-shelf (Davies) which had also been surveyed in 1980 but did not experience an infestation in 1983-84. The 3 mid-shelf reefs affected by $A$. planci were surveyed again in November 1984.

The $\log _{5}$ abundance categories of each species in a census were treated as being equivalent to log-transformed data, following Sale \& Williams (1982) and Russ $(1984 a, b)$ : thus, $1=1,2$ to $5=2,6$ to $25=3,26$ to $125=4,126$ to $625=5,626$ to $3250=6,>3250=7$. The abundance of each species on each reef from one census to the next was compared using 1-way analysis of variance or the t' test (which allows for heterogene-

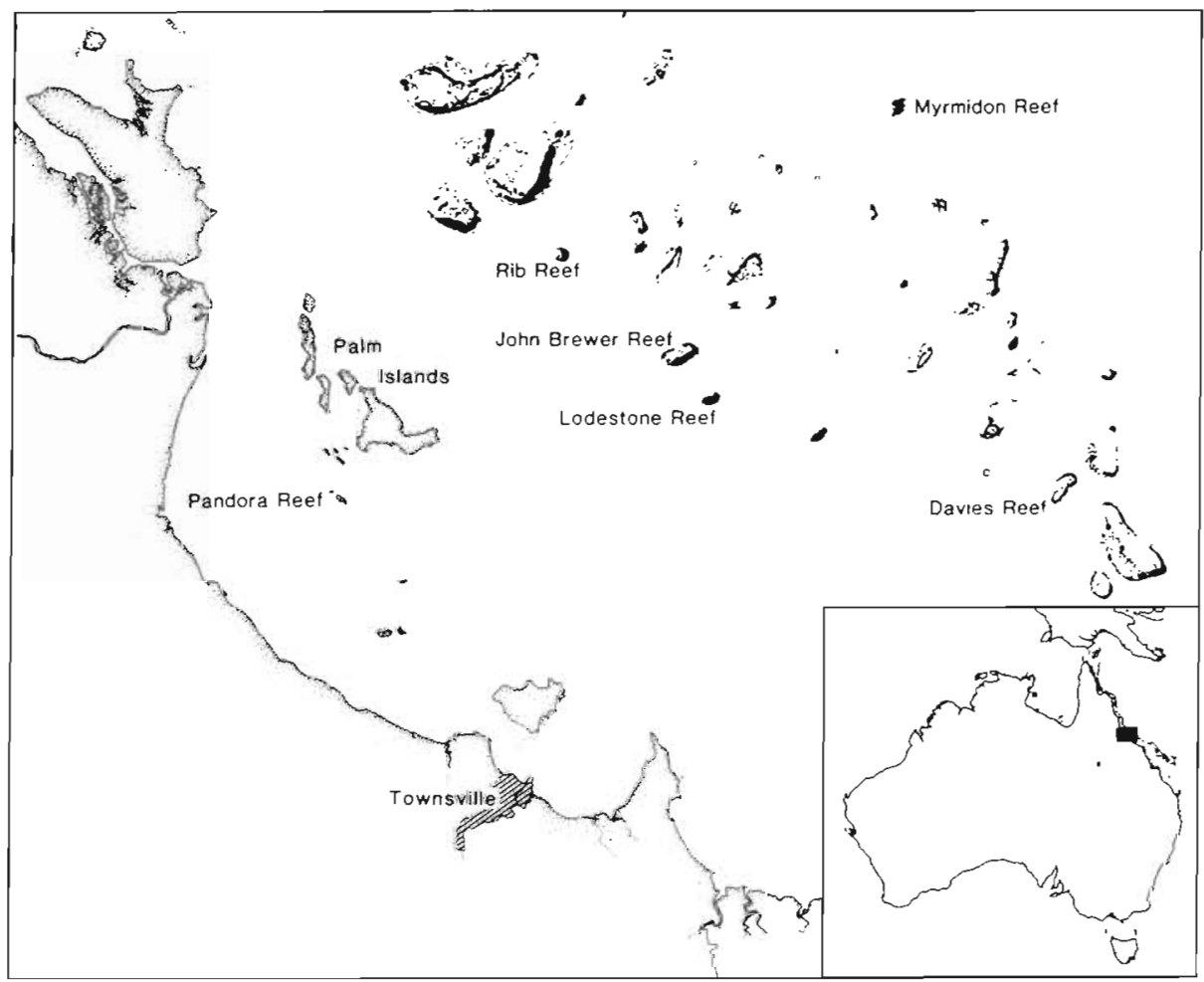

Fig. 1 Location of study reefs off Townsville 
ous variances, Sokal \& Rohlf 1969, p. 376) if variances were heterogenous according to Cochran's $C$ test (Winer 1971) - as they were in a minority of cases due to one of the means having a zero variance. Comparisons of abundances on the same reefs at different times are not totally independent (because similar sites were intentionally chosen each time) and so the data do not strictly meet one assumption of these parametric tests. However, examination of the data does not suggest that any of the results would have been confounded as a consequence. Analyses were attempted only when a species occurred in at least 3 censuses out of 5 (or 2 out of 4) on a given reef at any time. The large number of comparisons led to a high probability of making a Type I error [rejecting the hypothesis that the means are equal when in fact they are]. For each set of comparisons the number of expected differences due to a Type I error $[0.05 \times$ no. comparisons] was subtracted from the observed differences to estimate the actual number of differences.

\section{RESULTS}

The number of species sufficiently abundant to compare among reefs within shelf locations in 1980 varied from 62 to 69 , except for the 2 nearshore reefs where only 25 were sufficiently abundant. The number of actual differences in species abundances among reefs ranged from 1 to 13 (2 to $19 \%$ of comparisons) on the mid-and outer shelf reefs. Seven species (28\%) differed significantly in abundance among the 2 nearshore reefs (Table 1 ).
The number of species available for the 3 amonglocation comparisons in 1980 ranged from 67 to 81 (Table 1). The number of actual differences in species abundance among locations ranged from 35 to 60 (43 to $78 \%)$, considerably greater than the variation among reefs within a location.

In the 1980 vs 1983 comparison, the largest year-toyear variation in abundances within reefs occurred on the 3 mid-shelf reefs disturbed by Acanthaster planci aggregations in 1983 (Table 2). Even these latter changes, however, (4 to 9 changes, 6 to $15 \%$ of comparisons) were no greater than the differences among reefs at a given location at a particular time $(\mathrm{t}=1.42$, $\mathrm{df}=8, \mathrm{P}>0.20$ ). Year-to-year variation in abundances of species on reefs unaffected by $A$. planciaggregation ( 0 to $5 \%$ ) appeared less than differences among reefs at a given location at the one time ( 6 to $15 \%$ ) but was not significantly so $(\mathrm{t}=2.59$, df $=4, \mathrm{P}>0.05)$.

Given significant variation in the abundance of species in space and time in the absence of Acanthaster planci disturbance, some care needs to be taken in interpreting the effects of $A$. planci on the fish communities. Two criteria were chosen as evidence of a probable $A$. planci effect. The first, and most important, was that changes in abundance of fishes on $A$. planci affected reefs should be greater than those on the control reef over the same time. The second was that a similar change should occur on each of the affected reefs, or a least the effect should be most severe on the most severely disturbed reefs.

Because species that differ in their ecology - particularly their feeding behaviour - might be expected to

Table 1. Comparison of abundance of species within shelf locations and between shelf locations. Data collected in 1980. Percentage difference calculated as actual as a proportion of number of comparisons after subtracting expected differences. See text for details

\begin{tabular}{|c|c|c|c|c|}
\hline & No. comparisons & $\begin{array}{l}\text { No. sig. diffs. } \\
\text { observed }(O)\end{array}$ & $\begin{array}{c}\text { Expected } \\
\text { differences }(\mathrm{E}) \\
\text { due to Type I error }\end{array}$ & $\begin{array}{c}\text { Actual } \\
\text { differences }(\mathrm{O}-\mathrm{E})\end{array}$ \\
\hline \multicolumn{5}{|l|}{ Nearshore: } \\
\hline Pandora vs Philipps & 25 & 8 & 1 & $7(29 \%)$ \\
\hline \multicolumn{5}{|l|}{ Mid-shelf: } \\
\hline Rib vs Lodestone & 65 & 4 & 3 & $1(2 \%)$ \\
\hline Rib vs John Brewer & 66 & 14 & 3 & $11(18 \%)$ \\
\hline John Brewer vs Lodestone & 62 & 7 & 3 & $4(7 \%)$ \\
\hline \multicolumn{5}{|l|}{ Outer shelf: } \\
\hline Dip vs Bowl & 67 & 9 & 3 & $6(9 \%)$ \\
\hline Dip vs Myrmidon & 69 & 15 & 3 & $12(18 \%)$ \\
\hline Bowl vs Myrmidon & 69 & 16 & 3 & $13(20 \%)$ \\
\hline \multicolumn{5}{|l|}{ Cross-shelf: } \\
\hline Pandora vs Rib & 67 & 53 & 3 & $50(78 \%)$ \\
\hline Rib vs Mysmidon & 81 & 39 & 4 & $35(46 \%)$ \\
\hline Pandora vs Myrmidon & 77 & 64 & 4 & $60(82 \%)$ \\
\hline
\end{tabular}


Table 2. Comparison of abundances of species 1980 versus 1983, (except Davies 1980 vs 1984) []: excluding chaetodontids. See text for details

\begin{tabular}{|c|c|c|c|c|c|}
\hline \multirow[t]{2}{*}{ Reef } & \multirow[t]{2}{*}{ No. comparisons } & \multirow{2}{*}{$\begin{array}{l}\text { No. sig. diffs. } \\
\text { observed }(O)\end{array}$} & \multirow{2}{*}{$\begin{array}{c}\text { Expected } \\
\text { differences (E) }\end{array}$} & \multicolumn{2}{|c|}{ Actual diffs. $(O-E)$} \\
\hline & & & & Absolute & $\begin{array}{l}\text { Percentage of } \\
\text { total comparisons }\end{array}$ \\
\hline Pandora & 25 & 1 & 1 & 0 & $(0)$ \\
\hline Rib & $72[61]$ & $9[8]$ & $3[3]$ & $6[5]$ & (9) $[7]$ \\
\hline Lodestone & $63[54]$ & $7[2]$ & $3[3]$ & $4[-1]$ & (7) $[-2]$ \\
\hline John Brewer & $62[55]$ & $12[8]$ & $3[3]$ & $9[5]$ & (15) $[10]$ \\
\hline Myrmidon & 63 & 6 & 3 & 3 & $(5)$ \\
\hline Davies & 69 & 5 & 3 & 2 & (3) \\
\hline
\end{tabular}

Table 3. Comparison of numbers of acanthurids in 1980 (pre Acanthaster planci) versus June 1984 (post $A$. planci). Number of changes expected by chance alone $=1.6 ; \star=$ increase $1980-1984 ; i=$ decrease. One star, P $<.05 ; 2$ stars, $P<.01 ; 3$ stars, $\mathrm{P}<.001$

\begin{tabular}{|c|c|c|c|c|}
\hline & \multicolumn{3}{|c|}{ Acanthaster planci reefs } & \multirow{2}{*}{$\begin{array}{c}\text { Control reef } \\
\text { Davies }\end{array}$} \\
\hline & Lodestone & John Brewer & Rib & \\
\hline \multicolumn{5}{|l|}{ ACANTHURIDAE: } \\
\hline Acanthurus dussumieri & ns & ns & ns & \\
\hline A. glaucopareius & & & ns & \\
\hline A. lineatus & ns & ns & ns & ns \\
\hline A. 'mata' & ns & ns & & \\
\hline A. olivaceus & ns & & & \\
\hline A. triostegus & & & ns & \\
\hline Naso spp. & ns & & ns & ns \\
\hline N. Iituratus & $\star \star \star$ & & ns & \\
\hline N. tuberosus & & ns & ns & \\
\hline N. unicornis & ns & ns & ns & ns \\
\hline Zebrasoma scopas & ns & ns & ns & ns \\
\hline Z. veliferum & $\mathrm{ns}$ & ns & ns & ns \\
\hline 'Ctenochaetus' & ns & ns & ns & $\hat{t}$ \\
\hline - Includes Ctenochaets & grofuscus & & & \\
\hline
\end{tabular}

Table 4. Comparison of numbers of scarids in 1980 (pre Acanthaster planci) versus June 1984 (post $A$. plancl). Number of changes expected by chance alone $=2.1$. Details as in Table 3

\begin{tabular}{|c|c|c|c|c|}
\hline & \multicolumn{3}{|c|}{ Acanthaster planci reefs } & \multirow{2}{*}{$\begin{array}{c}\text { Control reef } \\
\text { Davies }\end{array}$} \\
\hline & Lodestone & John Brewer & Rib & \\
\hline \multicolumn{5}{|l|}{ SCARIDAE: } \\
\hline Cetoscarus bicolor & ns & ns & 额 & ns \\
\hline Scarus brevifilis & ns & ns & ns & ns \\
\hline S. rivulatus & ns & ns & ns & ns \\
\hline S. flavipectoralis & ns & ns & & ns \\
\hline S. psittacus & ns & ns & ns & \\
\hline S. spinus & ns & & ns & ns \\
\hline S. ghobban & $\star \star$ & & & \\
\hline S. gibbus & ns & ns & 论社 & ns \\
\hline S. globiceps & ns & ns & & ns \\
\hline Scarus sp. (cf. lunula) & ns & ns & ns & ns \\
\hline S. niger & ns & ns & ns & ns \\
\hline S. oviceps & ns & & ns & ns \\
\hline S. frenatus & ns & ns & ns & ns \\
\hline S. sordidus & ns & ns & ns & ns \\
\hline S. schlegeli & ns & ns & ns & ns \\
\hline Scarops rubroviolaceus & ns & ns & ns & ns \\
\hline
\end{tabular}


respond differently to the Acanthaster planci disturbance, the 5 major families surveyed were analysed separately (Tables 3 to 7 ). Changes in the abundance of acanthurids post $A$. plancidid not differ significantly from those expected by chance (Table 3 ) and there was only one more change in abundance of scarids than expected by chance (Table 4). There were a number of changes in the abundances of labrids (Table 5) and pomacentrids (Table 6) post $A$. planci but there were also significant changes within each family on the control reef. The abundance of no species of labrid or pomacentrid varied among reefs in a pattern that could be readily related to $A$. planci effects (Tables $5 \& 6$ ). In contrast, the chaetodontids demonstrated changes in abundances that can be readily ascribed to the effects of $A$. planci disturbance (Table 7 ). The 2 most abun-

Table 5. Comparison of numbers of labrids in 1980 (pre Acanthaster planci) versus June 1984 (post $A$. planci). Number of changes expected by chance alone $=1.4$. Details as in Table 3

\begin{tabular}{|c|c|c|c|c|}
\hline & \multicolumn{3}{|c|}{ Acanthaster planci reefs } & \multirow{2}{*}{$\begin{array}{c}\text { Control ree } \\
\text { Davies }\end{array}$} \\
\hline & Lodestone & John Brewer & Rib & \\
\hline \multicolumn{5}{|l|}{ LABRIDAE: } \\
\hline Coris gaimardi & ns & & ns & \\
\hline Epibulus insidiator & $\star \star$ & ns & & ns \\
\hline Gomphosus varius & ns & ns & ns & ns \\
\hline Halichoeres hortulanus & ns & ns & ns & ns \\
\hline Hemigymnus fasciatus & ns & ns & ns & ns \\
\hline H. melapterus & ns & ns & ns & ns \\
\hline Choerodon fasciatus & ns & s & ns & \\
\hline Thalassoma hardwickei & ns & ns & ns & ns \\
\hline T. janseni & ns & $\star \star$ & ns & ns \\
\hline T. Iunare & ns & sis & ns & 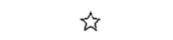 \\
\hline T. Iutescens & & & & ns \\
\hline
\end{tabular}

Table 6. Comparison of numbers of promacentrids in 1980 (pre Acanthaster planci) versus June 1984 (post $A$. planci). Number of changes expected by chance alone $=3.1$. Details as in Table 3

\begin{tabular}{|c|c|c|c|c|}
\hline & \multicolumn{3}{|c|}{ Acanthaster planci reefs } & \multirow{2}{*}{$\begin{array}{c}\text { Control reef } \\
\text { Davies }\end{array}$} \\
\hline & Lodestone & John Brewer & Rib & \\
\hline \multicolumn{5}{|l|}{ POMACENTRIDAE: } \\
\hline Acanthochromis polyacanthus & ns & ns & ns & ns \\
\hline Abudefduf sexfasciatus & & & ns & ns \\
\hline A. saxatilis & & & ns & \\
\hline A. whitleyi & ns & ns & $\hat{\omega} \hat{\imath}$ & ns \\
\hline Chromis atripectoralis & ns & ns & ns & ns \\
\hline C. margaritifer & & 它 & ns & ns \\
\hline C. nitida & ns & ns & & ns \\
\hline C. ternatensis & & ns & ns & ns \\
\hline Dascyllus reticulatus & ns & ns & ns & \\
\hline Glyphidodontops rex & & & ns & \\
\hline G. rollandi & ns & ns & ns & ns \\
\hline G. talboti & ns & ns & ns & 的象 \\
\hline Neopomacentrus azysron & ns & ns & ns & ns \\
\hline Pomacentrus amboinensis & ns & ns & ns & ns \\
\hline P. coelestis & ns & $\hat{n}$ & ns & ns \\
\hline P. lepidogenys & ns & ns & ns & ns \\
\hline Pomacentrus $\mathrm{sp}$. & & ns & $\hat{s}$ & s \\
\hline P. philippinus & ns & ns & ns & ns \\
\hline P. popei & ns & $\mathrm{ns}$ & $\hat{z}$ & w \\
\hline P. wardi & ns & 论视 & ns & ns \\
\hline Plectroglyphidodon dickii & ns & ns & & \\
\hline P. lacrymatus & ns & ns & ns & ns \\
\hline Stegastes apicalis & ns & ns & ns & ns \\
\hline S. fasciolatus & ns & $\star \star \star \star$ & ns & \\
\hline
\end{tabular}


Table 7. Comparison of numbers of chaetodontids in 1980 (pre Acanthaster planci) versus June 1984 (post A. planci). Number of changes expected by chance alone $=1.4 .(C F)=$ obligate scleractinian feeder. Details as in Table 3

\begin{tabular}{|c|c|c|c|c|}
\hline & \multicolumn{3}{|c|}{ Acanthaster planci reefs } & \multirow{2}{*}{$\begin{array}{c}\text { Control reef } \\
\text { Davies }\end{array}$} \\
\hline & Lodestone & John Brewer & Rib & \\
\hline \multicolumn{5}{|l|}{ CHAETODONTIDAE: } \\
\hline Chaetodon aureofasciatus (CF) & 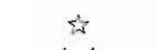 & ts & 抒 & ns \\
\hline C. baronessa (CF) & the & ns & ns & ns \\
\hline C. citrinellus & ns & & ns & ns \\
\hline C. lineolatus & & & ns & \\
\hline C. melannotus & & & $\star \star \star$ & ns \\
\hline C. plebius (CF) & 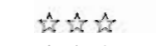 & 故公 & ns & \\
\hline C. rainfordi (CF) & 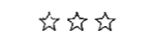 & 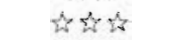 & 地公的 & \\
\hline C. trifascialis (CF) & ns & ns & ns & \\
\hline C. trifasciatus (CF) & ns & ns & ns & \\
\hline C. vagabundis & ns & ns & ns & ns \\
\hline Chelmon rostratus & ns & ns & & ns \\
\hline
\end{tabular}

dant species of scleractinian-feeding chaetodontids on the mid-shelf, Chaetodon aureofasciatus and C. rainfordi (Williams 1982) were each significantly less abundant after disturbance on all $3 \mathrm{~A}$. planci affected reefs. Two other coral-feeding chaetodontids, $C$. baronessa and $C$. plebius were significantly less abundant on Lodestone, the reef most extensively damaged by $A$. planci, and one of these, $C$. plebius, also decreased in abundance on John Brewer post $A$. planci. Only 1 chaetodontid that was not a coral-feeding specialist changed in abundance over the same period $-C$. melannotus increased in abundance on Rib reef. There were no changes in the abundance of chaetodontids on the control reef over the same period (Table 7).

The changes in species abundance between 1980 and June 1984 (Tables 3 to 7 ) suggest that species of some families (Pomacentridae, Labridae) might be inherently more variable than others (Scaridae, Acanthuridae). A familial breakdown of changes in species abundances in November 1983, June 1984 and November 1984 versus 1980 suggests these observations may not, however, have generality (Table 8).

Table 8 . Temporal variation in species abundances by family. Total number of incidences of significant variation $(O-E)$, pooled over Rib, John Brewer and Lodestone Reefs. See Table 1 and text for details

\begin{tabular}{|lccc|}
\hline & \multicolumn{3}{c|}{1980 versus: } \\
& Nov 83 & Jun 84 & Nov 84 \\
\hline Chaetodontidae & 9 & 9 & 11 \\
Labridae & 1 & 3 & 0 \\
Pomacentridae & 3 & 5 & 6 \\
Acanthuridae & 2 & 0 & -1 \\
Scaridae & 4 & 1 & 2 \\
\hline
\end{tabular}

\section{DISCUSSION}

The results demonstrate that significant temporal variation in the abundances of species within reefs does occur over years. Only a relatively small proportion of the species on a reef showed significant variation between the years censused but a relatively coarse measure of abundance $\left(\log _{5}\right)$ was used and only large changes in abundance (several-fold) could have been detected by the analysis. That significant variation was observed, despite the relative weakness of the test, emphasizes that some of the temporal variation is large and suggests that further, albeit smaller, changes may have been detected if a more powerful test had been used.

Differences in species abundances between reefs within a shelf location were similar to, or greater than, temporal variation within reefs but were much less than differences across the shelfs. These spatial comparisons emphasize previous observations (Williams 1982 , 1983) of the magnitude of cross-shelf variation. Comparisons of spatial variation with the temporal variability suggest that the observed cross-shelf variation in structure of fish communities and even some differences between reefs at the same shelf location are likely to be relatively constant in time (years). If differences among reefs (as measured by the present techniques) are less than, say $10 \%$ of the species compared, however, particular care will need to be taken in interpreting the significance of the spatial variation since the patterns may not be persistent between years. The proximate causes of both the spatial and temporal variation in community structure, in particular the role of larval recruitment patterns, are currently being examined.

This paper demonstrates that infestations of Acanthaster planci can have a significant effect on at least 
1 group of reef fishes. It is not surprising that the first group of fishes to be affected significantly by an extensive reduction in cover of live scleractinian corals are obligate feeders on the corals - the chaetodontids Chaetodon aureofasciatus, C. rainfordi, C. plebius and probably $C$. baronessa (Anderson et al. 1981). Sano et al. (1984) made a similar observation. One wonders why the other 2 relatively common scleractinian feeders, C. trifascialis and C. trifasciatus, did not also show significant changes in abundances. The decrease in chaetodontids following reduction in live cover by A. planci was impressive. Changes in the abundance of coral feeding chaetodontids might give some indication of the 'health' (i.e. live coral cover) of coral reefs as suggested by Reese (1977), but our observations lead us to question their value as 'indicator' organisms since infestations of $A$. planci and extensive decrease in live coral cover were obvious to even a casual observer before obvious changes occurred in chaetodontid abundance.

Adult starvation and mortality following massive reduction in live coral cover was almost certainly the mechanism causing reduction in the abundance of chaetodontids, but the reduction in coral cover caused by Acanthaster planci could potentially affect reef fishes in several other ways. Growth rates of adults, and hence fecundity and perhaps susceptibility to predation, could vary as the amount of live coral decreases, algal abundance increases and associated invertebrates vary accordingly. Recruitment might vary as a result of habitat selection by recruits for areas for live coral or high algal cover. Mortality rates of juveniles might be influenced by changes in the availability of food associated with the change in cover of live scleractinian coral. Each of these mechanisms could potentially cause changes in the abundance of fish species over longer periods than that studied here (approx. 12 to 18 mo post A. planci infestation) and could result in either increases or decreases in abundance of particular species depending upon their diet. Sano et al. (1984) found that structural collapse of dead Acropora colonies as a result of bio- and physical erosion led to significant decreases in species diversity and numbers of individual fishes in the corals. Of these additional mechanisms, we so far have data only on changes in recruitment post $A$. planci. Of those species for which data is available, 21 differed significantly in abundance of recruits to Rib, John Brewer, and Lodestone in $1982 / 83$ (pre $A$. plancl) compared to $1983 / 84$ (post $A$. plancl). Of these, a disproportionate number (17) were less abundant post $A$. planci than pre $A$. planci. Those species closely associated with live coral at recruitment (e.g. Chromis atripectoralis, Chaetodon aureofasciatus, C. rainfordi, Labrichthys unilineata, Pomacentrus popei $[=$ molluccensis $]$ ) were dispropor- tionately less abundant post $A$. planci than other species (Williams \& S. A. English unpubl.). Longerterm studies of the fish communities in the present study will be required to determine whether or not A. planci infestations have long-term effects on the adult densities of fishes other than the scleractinianfeeding chaetodontids.

\section{LITERATURE CITED}

Anderson, G. R. V., Ehrlich, P. R., Roughgarden, J. D., Russell, B. C., Talbot, F. H. (1981). The community structure of coral reef fishes. Am. Nat. 117: 446-495

Cheney, D. P. (1972). Guam and the crown-of-thorns starfish. Guam Recorder 1: 74-80

Chesher, R. H. (1969). Acanthaster planci: Impact on Pacific coral reefs. Report to US Dept. Interior, No. PB 187631. Westinghouse Electric Co.

Endean, R. (1973). Population explosions of Acanthaster planci and associated destruction of hermatypic corals in the Indo-West Pacific Region. In: Jones, O. A., Endean, R. (ed.) Biology and geology of coral reefs Vol. II. Biology 1. Academic Press, New York, 389-438

Endean, R., Stablum, W. (1973). The apparent extent of recovery of reefs of Australia's Great Barrier Ref devastated by the crown-of-thorns starfish. Atoll Res. Bull 168: 1-37

Reese, E. S. (1977). Coevolution of corals and coral feeding fishes of the family Chaetodontidae. Proc. Third Int. Coral Reef Symp., Vol. 2. University of Miami, Miami p. 268-274

Russ, G. (1984). Distribution and abundance of herbivorous grazing fishes in the central Great Barrier Reef. I. Levels of variability across the entire continental shelf. Mar. Ecol. Prog. Ser. 20: 23-34

Russ, G. (1984b). Distribution and abundance of herbivorous grazing fishes in the central Great Barrier Reef. II. Patterns of zonation of mid-shelf and outer shelf reefs. Mar. Ecol. Prog. Ser. 20: 35-44

Sale, P. F., Douglas, W. A. (1984). Temporal variability in the community structure of fish on coral patch reefs, and the relation of community structure to reef structure. Ecology 65: 409-422

Sale, P. F., Williams, D. McB. (1982). Community structure of coral reef fishes: are the patterns more than those expected by change? Am. Nat. 120, 121-127

Sano, M., Shimizu, M., Nose, Y. (1984). Changes in structure of coral reef fish communities by destruction of hermatypic corals: observational and experimental view. Pacif. Sci. 38: 51-79

Sokal, R. R., Rohlf, F. J. (1969). Biometry. W. H. Freeman and Co., San Francisco

Talbot, R. H., Russell, B. C., Anderson, G. R. V. (1978). Coral reef fish communities: unstable, high-diversity systems? Ecol. Monogr. 48: 425-440

Williams, D. McB. (1980). Dynamics of the pomacentrid community on small patch reefs in One Tree Lagoon (Great Barrier Reef). Bull. mar. Sci. 30: 159-170

Williams, D. McB. (1982). Patterns in the distribution of fish communities across the Central Great Barrier Reef. Coral Reefs 1: 35-43

Williams, D. McB. (1983). Longitudinal and latitudinal variation in the structure of reef fish communities. In: Baker, J. J., Carter, R. M., Sammarco, P. W., Stark, K. P.(ed.) Proc. 
Inaugural Great Barrier Reef Conf., Townsville 1983. JCU Townsville, p. 265-270

Williams, D. McB., Hatcher, A. I. (1983). Structure of fish communities on outer slopes of inshore, mid-shelf and outer shelf reefs of the Great Barrier Reef. Mar. Ecol. Prog Ser. 10: 239-250

Winer, B. (1971). Statistical principles in experimental design. 2nd edn. McGraw-Hill, New York

This paper was presented by Dr. M. Pichon; it was accepted for printing on October 2, 1985 